\title{
Summer roadside vegetation dominated by Sorghum halepense in peninsular Italy: survey and classification
}

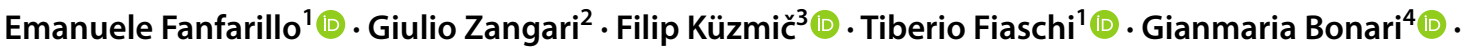 \\ Claudia Angiolini ${ }^{1}$ (1)
}

Received: 18 October 2021 / Accepted: 12 January 2022 / Published online: 3 February 2022

(c) The Author(s) 2022

\begin{abstract}
Sorghum halepense is a synanthropic tall grass distributed worldwide from tropical to temperate zones, and it is often considered an invasive alien. It is a perennial, rhizomatous plant that tends to form dense stands derived from vegetative and sexual propagation. Despite roadside plant communities dominated by Sorghum halepense are very common in southern Europe, their phytosociological aspects are scarcely studied. In this work, we present the results of a vegetation survey in peninsular Italy, carried out by means of the phytosociological method. In total, we carried out 73 relevés in Liguria, Tuscany, Latium, Campania, Basilicata, and Apulia. We statistically compared our relevés to those from the Balkans classified in the Cynodonto-Sorghetum halepensis, an association of agricultural annual weed vegetation of the class Stellarietea mediae s.l. used in the past as a reference for Italian S. halepense-dominated communities. Our results show that the Italian communities are different from the Cynodonto-Sorghetum halepensis communities, since the latter are rich in annual species, while the former are rich in perennial species. From the syntaxonomic point of view, the Italian communities are better classified in the class Artemisietea vulgaris. We describe the new (sub-)ruderal association Potentillo reptantis-Sorghetum halepensis, including a meso-hygrophilous variant with Urtica dioica and an agricultural variant with Elymus repens. We have evidence that the Potentillo-Sorghetum occurs in Italy, Kosovo and Slovenia, but its distribution is possibly wider due to conspicuous presence of cosmopolitan species characterizing the association. Our work provides a baseline for the knowledge of an alien-dominated plant community that can invade habitats with high conservation value.
\end{abstract}

Keywords Archaeophyte $\cdot$ Johnson grass $\cdot$ Phytogeography $\cdot$ Phytosociology $\cdot$ Syntaxonomy $\cdot$ Weed

\section{Introduction}

The introduction of plant species outside their native range is one of the main ecological threats of modern times. This is especially true for invasive alien species that can establish and rapidly spread in new areas outcompeting native biodiversity, degrading natural ecosystems, and producing relevant economic losses (Seebens et al. 2017; Lazzaro et al. 2020).

1 Department of Life Sciences, University of Siena, Via P.A. Mattioli 4, 53100 Siena, Italy

2 Department of Sciences, University of Roma Tre, Via Ostiense 159, 00154 Rome, Italy

3 Research Centre of the Slovenian Academy of Sciences and Arts, Jovan Hadži Institute of Biology, Novi trg 2, 1000 Ljubljana, Slovenia

4 Faculty of Science and Technology, Free University of Bozen-Bolzano, Piazza Università 5, 39100 Bolzano, Italy 
In Europe, non-native plants are traditionally divided into archaeophytes, introduced before 1492, and neophytes, introduced after 1492. Generally, archaeophytes are not considered a major threat to biodiversity since they behave mostly as agricultural weeds (Celesti-Grapow et al. 2009). In this latter scenario, they are considered a valuable component of the Italian flora. They survive only in extensively managed winter arable crops and are often threatened by agricultural intensification (Fanfarillo et al. 2020; Orsenigo et al. 2021). There are a few exceptions of archaeophytes that produce high negative impacts on native biodiversity and natural habitats. One exception is Sorghum halepense (L.) Pers., which is considered an invasive archaeophyte in Italy (Galasso et al. 2018; Lazzaro et al. 2020).

Sorghum halepense, commonly known as Johnson grass, is a perennial, rhizomatous plant widely distributed in warm areas worldwide. It belongs to the Panicoideae, a subfamily of the Poaceae that includes very competitive, thermophilous grasses with a highly efficient C4 metabolism (Giussani et al. 2001). Within the Panicoideae, it is classified into the Andropogoneae, a tribe that has its main center of diversity in tropical and subtropical regions (Arthan et al. 2017). However, there is contrasting information about its native range. Different sources report the species to be native in different areas between the Mediterranean and eastern Asia (CABI 2021). In the last decades, the species has spread considerably in agricultural and ruderal habitats in Europe and other continents, favored by both man activities and an increasingly warmer climate (Follak and Essl 2013; Follak et al. 2017; Peerzada et al. 2017; Fanfarillo et al. 2019).

Sorghum halepense is considered among the worst agricultural weeds worldwide (Holm et al. 1977). Especially in arable land, its success is favored by herbicide resistance and the spread of rhizomes through tillage (Vila-Aiub et al. 2007; Heap 2014; Kashif et al. 2015). Glyphosate-resistant ruderal populations are also known in Spain (Vazquez-Garcia et al. 2020). In Italy, Sorghum halepense is among the few alien species that occur in all the administrative regions (Stinca et al. 2021). It is one of the few archaeophytes to be invasive and to have a relevant impact on Natura 2000 habitats (Galasso et al. 2018). The species is capable of invading and modifying different EU habitats as "rivers with muddy banks with Chenopodion rubri p.p. and Bidention p.p. vegetation" (habitat code: 3270), "Oligotrophic to mesotrophic standing waters with vegetation of the Littorelletea uniflorae and/or of the Isoëto-Nanojuncetea" (habitat code: 3130), and "Hydrophilous tall herb fringe communities of plains and of the montane to alpine levels" (habitat code: 6430). The detrimental effects of invasion include habitat degradation and loss, modification of successional patterns, and reduction of native biodiversity (Lazzaro et al. 2020).

Despite being a perennial species, Sorghum halepense is usually considered characteristic of annual synanthropic vegetation types (Biondi et al. 2014; Mucina et al. 2016). Given its relevance as an agricultural weed, most of the phytosociological studies on Eurasian communities with Sorghum halepense were carried out on annual vegetation of arable land, neglecting ruderal vegetation (Baldoni 1995; Poldini et al. 1998; Mitić et al. 2009; Nowak and Nowak 2013; Fanfarillo et al. 2019). In Central Italy, Baldoni (1995) described the sub-association Panico-Polygonetum persicariae sorghetosum halepensis for the weed vegetation of summer-annual crops of Marche. This syntaxon has been recently detected also elsewhere in Central Italy, i.e., in Latini et al. (2020). In eastern Europe and Middle Asia, summer arable weed communities were identified as the Setario ambiguae-Sorghetum halepensis (Nowak and Nowak 2013), while the association Hibisco trioni-Sorghetum halepensis was described for the same ecological contexts in Dalmatia (Croatia) (Mitić et al. 2009). In Romania, Ştefan and Oprea (1997) described two associations of arable land, namely Setario lutescentis-Sorghetum halepensis and Cynancho acuti-Sorghetum halepensis, which colonize different crops.

A few studies investigated perennial Sorghum halepensedominated plant communities. In the perennial ruderal grasslands of Styria (Austria), Sorghum halepense characterizes a thermophilous subtype of the association Convolvulo arvensis-Agropyretum repentis, in the class Artemisietea vulgaris (Denk and Berg 2014). A perennial ruderal community dominated by Sorghum halepense, rich in tropical species, was also described in Cuba as Sorghetum halepensis (Ricardo Nápoles et al. 2005). In a fluvial ecosystem of Marche (central Italy), Biondi et al. (2009) classified perennial Sorghum halepense-dominated vegetation in the association Cynodonto-Sorghetum halepensis. According to Viciani et al. (2020), this association was also reported by Brullo et al. (2001) for Calabria (southern Italy). This is a mistake, since no reference to the Cynodonto-Sorghetum halepensis is present in Brullo et al. (2001). Some communities dominated by Sorghum halepense were also reported by De Marchi et al. (1979) growing on the gravel banks of the Parma River, Emilia-Romagna (northern Italy). In the metropolitan area of Rome (Italy), Fanelli (2002) identified a ruderal vegetation type dominated by Sorghum halepense and classified it in the alliance Convolvulo arvensis-Agropyrion repentis of the class Artemisietea vulgaris. The author recognized the strong identity of such community, suggesting the possibility of describing an association in future.

Based on the above-mentioned studies, two syntaxa dominated by Sorghum halepense are reported for Italy: Cynodonto-Sorghetum halepensis and Panico sanguinalis-Polygonetum persicariae sorghetosum halepensis, both included in the class Stellarietea mediae, plus a Sorghum halepense community included in the class Artemisietea vulgaris (Viciani et al. 2020). The scarce investigations carried out on perennial Sorghum halepense-dominated 
vegetation in Italy imply that most of the impact assessments recognizing this species as a high-impact invader are expertbased (Lazzaro et al. 2020). To improve the knowledge of this vegetation type, we carried out a phytosociological survey on Sorghum halepense-dominated communities of peninsular Italy to study the floristic, ecological, chorologi$\mathrm{cal}$, and syntaxonomic aspects, comparing them with similar plant communities in the Balkans.

\section{Materials and methods}

\subsection{Study area}

The area of the field survey extends along peninsular Italy, from the southeastern-most part of Liguria to Salento area, in Apulia (approximately $44^{\circ} \mathrm{N}-10^{\circ} \mathrm{E} ; 40^{\circ} \mathrm{N}-18.5^{\circ} \mathrm{E}$; Fig. 1).
There are two main bioclimatic types: Mediterranean, including most of the Tyrrhenian coast, the southern half of the Adriatic coast, and southern regions excluding high mountains, and Temperate, including inner areas of the Peninsula and the northern half of the Adriatic coast. These two climatic zones are distinguished by the presence and absence of summer drought, respectively (Pesaresi et al. 2017).

The Italian Peninsula is mostly hilly and mountainous. Geological substrates are mainly sedimentary rocks (limestone, flysch, dolomite), but several volcanoes are present along the Tyrrhenian side between southern Tuscany and northern Campania, as well as some metamorphic lithotypes. Recent alluvial deposits occur in plains and valleys (ISPRA 2021).

\subsection{Field and literature survey}

During botanical field surveys in summer 2020, we recorded plant communities dominated by Sorghum halepense along
Fig. 1 Distribution of the phytosociological relevés (red dots) carried out in summer 2020 in Italy. BAS Basilicata, CAM Campania, LAZ Latium, LIG Liguria, PUG Apulia, TOS Tuscany. Region codes follow Bartolucci et al. (2018)

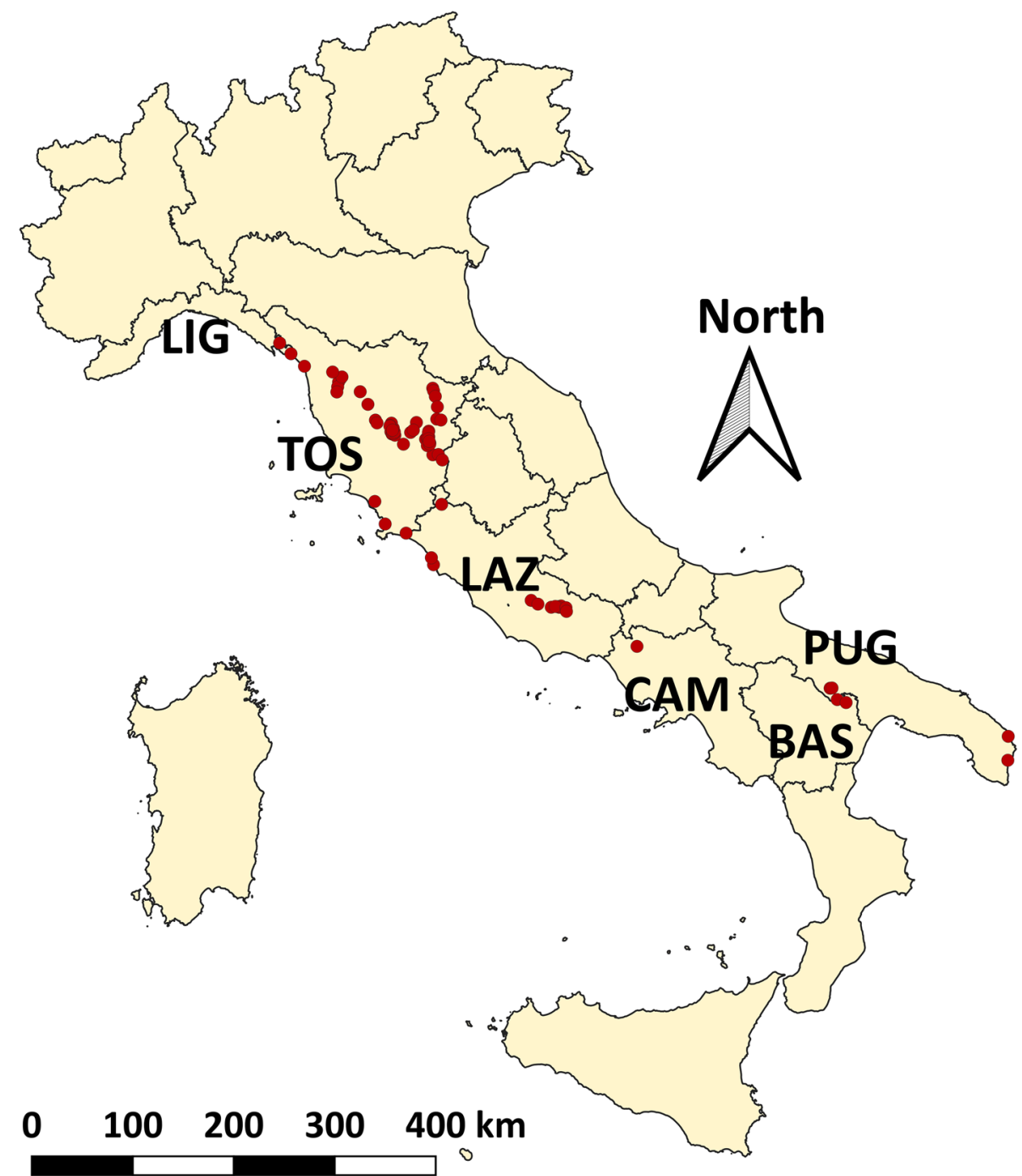


roadsides and adjacent sites, like ditches and fallows, in several regions of peninsular Italy. The relevés were carried out using the classic phytosociological method of the ZürichMontpellier school (Braun-Blanquet 1964). We carried out 73 relevés in 6 Italian regions (Liguria, Tuscany, Latium, Campania, Basilicata, and Apulia) (Fig. 1). Additionally, we searched for published relevés with dominant Sorghum halepense in Italian literature and vegetation plot repositories, excluding data from arable vegetation. Seven further Italian relevés were retrieved from literature and from the Archive database (specifically for Latium and Umbria regions; Fanelli 2002; Lucarini et al. 2015).

Despite arable vegetation was excluded from our study, the arable association Cynodonto-Sorghetum halepensis was the only low-rank syntaxon used as a reference for Italian non-agricultural Sorghum halepense-dominated vegetation. Thus, to compare the Cynodonto-Sorghetum halepensis with our communities and verify possible differences, we digitized 50 relevés used for its original description in Kosovo (Laban 1975). For the same purpose, we digitized and stored 14 Slovenian relevés attributed to the same association (Seljak 1989; Kaligarič 1992). The final database included 143 relevés.

Species nomenclature follows the Portal to the Flora of Italy version 2021.1 (2021). Syntaxonomic nomenclature follows Mucina et al. (2016) for alliances, orders, and classes, and the original authors for lower-rank syntaxa. To establish the names of the new syntaxa, we followed Theurillat et al. (2021). For the abbreviation codes of Italian administrative regions, we referred to Bartolucci et al. (2018).

\subsection{Statistical analyses}

We used a divisive cluster analysis, such as the modified TWINSPAN (Roleček et al. 2009) in the program JUICE, version 7.1.27 (Tichý 2002), using 5 pseudo-species cut levels $(0 \%, 2 \%, 5 \%, 10 \%, 20 \%$; minimum group size $=5)$ and total inertia as a dissimilarity measure. Diagnostic species for each resulting cluster were determined through the phi coefficient (Chytrý et al. 2002) (zero fidelity given to species with no statistical significance at $p>0.05$ ), and the size of all the groups was standardized to equal size (Tichý and Chytrý 2006). Furthermore, we carried out a Non-metric Multidimensional Scaling ordination analysis (NMDS; dissimilarity index: Bray-Curtis) using the R package "mass" (Venables and Ripley 2002; Oksanen et al. 2020).

To highlight differences in life forms and chorology, we calculated frequency-weighted life form and chorological spectra for the main vegetation types detected. Life forms and chorotypes are according to Pignatti et al. (2017-2019). To highlight ecological differences between the vegetation types, we calculated the mean Ellenberg indicator values adapted to the flora of Italy (Pignatti et al. 2005), which were then passively projected on the NMDS plot.

\section{Results}

\subsection{Detected vegetation types}

The modified TWINSPAN classification produced four ecologically and floristically interpretable clusters. The first division separated the Balkan (cluster 1) from the Italian (clusters 2, 3, and 4) relevés. While no Italian relevés were classified in the first cluster, eight Balkan relevés were included in the second: seven from Slovenia in cluster 2 and one from Kosovo in cluster 4 (Fig. 2).

Table 1 shows the percentage frequencies and fidelity values of the four clusters. Arable and ruderal species like Amaranthus retroflexus, Cirsium arvense, and Chenopodium album show high frequency and fidelity in the Balkan communities, while they are almost absent in Italian ones. In the latter, perennial species, such as Equisetum ramosissimum, Potentilla reptans, and Silene latifolia, frequently accompany Sorghum halepense. The full analytic tables of the relevés are available in Online Resource 1.

The distribution of the relevés on the NMDS ordination graph is consistent with the results of the modified TWINSPAN classification. Most of the variability in species composition is explained by the first axis. Along this axis, the highlighted Ellenberg indicator values for temperature and soil reaction explain this gradient. A second gradient explained by increasing moisture and decreasing continentality was also detected (Fig. 3).

The comparison of the frequency-weighted life form spectra highlights remarkable differences between the Balkan (cluster 1) and the Italian (clusters 2, 3, and 4) plant communities. The former are annual, while the latter are perennial, being featured by a high number of hemicryptophytes

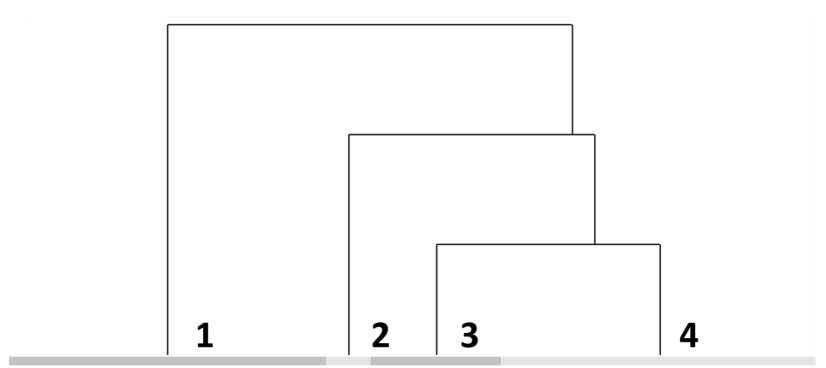

Fig. 2 Dendrogram showing the results of the modified TWINSPAN cluster analysis of the 143 relevés. 1=Cynodonto-Sorghetum halepensis (56 relevés); $2=$ Potentillo reptantis-Sorghetum halepensis var. with Elymus repens (8 relevés); $3=$ Potentillo reptantisSorghetum halepensis var. with Urtica dioica (23 relevés); $4=$ Potentillo reptantis-Sorghetum halepensis (56 relevés) 
Table 1 Synoptic table with decreasing percentage frequency (left value) and fidelity (phi coefficient - right apex value) of diagnostic species (highlighted in the boxes) for the four clusters resulted from the modified TWINSPAN classification; --- $=0 ; 1=$ CynodontoSorghetum halepensis; $2=$ Potentillo reptantis-Sorghetum halepensis var. with Elymus repens; 3=Potentillo reptantis-Sorghetum halepensis var. with Urtica dioica; $4=$ Potentillo reptantis-Sorghetum halepensis

\begin{tabular}{|c|c|c|c|c|}
\hline Cluster & 1 & 2 & 3 & 4 \\
\hline Number of relevés & 56 & 8 & 23 & 56 \\
\hline Amaranthus retroflexus & $36^{52.2}$ & --- & --- & $2^{---}$ \\
\hline Senecio vulgaris & $32^{51.2}$ & --- & -- & --- \\
\hline Chenopodium album & $46^{50.3}$ & $12^{---}$ & --- & $2^{---}$ \\
\hline Cirsium arvense & $80^{50.1}$ & $38^{---}$ & $26^{---}$ & $9^{---}$ \\
\hline Echinochloa crus-galli & $27^{46.4}$ & --- & --- & --- \\
\hline Bromus arvensis & $27^{46.4}$ & --- & --- & --- \\
\hline Anthemis arvensis & $25^{44.7}$ & --- & --- & --- \\
\hline Sonchus arvensis & $36^{42}$ & $12^{---}$ & --- & --- \\
\hline Torilis arvensis & $20^{36.6}$ & --- & --- & $2^{---}$ \\
\hline Anisantha sterilis & $20^{36.6}$ & --- & --- & $2^{---}$ \\
\hline Aristolochia clematitis & $16^{35.4}$ & -- & --- & --- \\
\hline Calepina irregularis & $16^{35.4}$ & -- & --- & --- \\
\hline Poa trivialis & $14^{33.3}$ & --- & --- & --- \\
\hline Capsella bursa-pastoris & $14^{33.3}$ & --- & --- & --- \\
\hline Persicaria lapathifolia & $14^{33.3}$ & --- & --- & --- \\
\hline Linaria vulgaris & $27^{33.1}$ & --- & $9^{---}$ & $4^{---}$ \\
\hline Arabidopsis thaliana & $12^{31.1}$ & --- & --- & --- \\
\hline Xanthium strumarium & $12^{31.1}$ & --- & --- & --- \\
\hline Alopecurus myosuroides & $14^{30.2}$ & --- & --- & $2^{---}$ \\
\hline Veronica persica & $14^{30.2}$ & --- & --- & $2^{---}$ \\
\hline Convolvulus sepium & $4^{---}$ & $88^{72.1}$ & $26^{---}$ & $4^{---}$ \\
\hline Erigeron аппииs & $2^{---}$ & $38^{51.8}$ & -- & $2^{---}$ \\
\hline Lactuca serriola & $30^{3.6}$ & $62^{45.1}$ & $17^{---}$ & --- \\
\hline Elymus repens & $39^{2.1}$ & $75^{44.7}$ & $30^{---}$ & $5^{---}$ \\
\hline Tussilago farfara & $2^{---}$ & $25^{42.3}$ & --- & --- \\
\hline Setaria pumila & $32^{16.6}$ & $50^{42.1}$ & --- & --- \\
\hline Artemisia vulgaris & $7^{---}$ & $38^{41}$ & $9^{---}$ & --- \\
\hline Vicia cracca & $7^{---}$ & $25^{36}$ & --- & --- \\
\hline Trifolium repens & $2^{---}$ & $25^{31.2}$ & $9^{---}$ & $2^{---}$ \\
\hline Galium album & --- & --- & $48^{58.7}$ & $5^{---}$ \\
\hline Equisetum ramosissimum & --- & --- & $57^{57.5}$ & $16^{---}$ \\
\hline Urtica dioica & $5^{---}$ & --- & $39^{51.4}$ & --- \\
\hline Silene latifolia & --- & $12^{---}$ & $52^{48.1}$ & $12^{---}$ \\
\hline Rubus ulmifolius & --- & --- & $43^{46.4}$ & $16^{--}$ \\
\hline Mentha spicata & --- & --- & $22^{38.9}$ & $2^{---}$ \\
\hline Mentha suaveolens & --- & --- & $22^{38.9}$ & $2^{---}$ \\
\hline Foeniculum vulgare & --- & --- & --- & $16^{35.4}$ \\
\hline Medicago sativa & --- & --- & $4^{---}$ & $21^{35.2}$ \\
\hline Sorghum halepense & $45^{---}$ & $62^{---}$ & $100^{31.7}$ & $100^{31.7}$ \\
\hline Potentilla reptans & $5^{---}$ & $50^{---}$ & $52^{21.5}$ & $30^{---}$ \\
\hline Avena sterilis & --- & --- & --- & $11^{28.7}$ \\
\hline Avena barbata & --- & $12^{---}$ & $13^{---}$ & $21^{17.4}$ \\
\hline
\end{tabular}

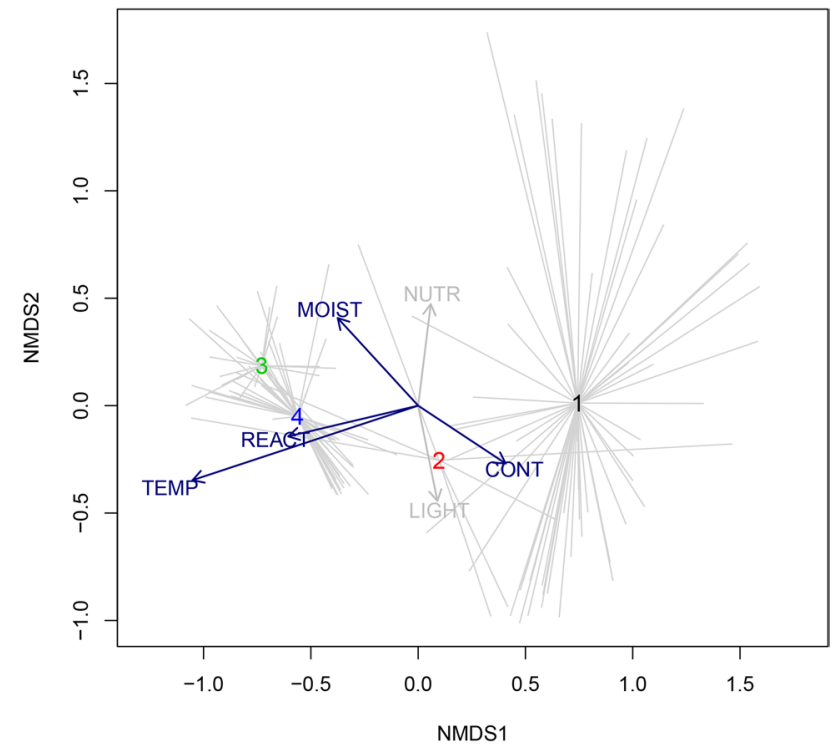

Fig. 3 Non-metric Multidimensional Scaling ordination analysis of the 143 relevés with Ellenberg indicator values (significant factors highlighted in bold) passively projected on the graphic (stress $=0.19$ ). The numbers correspond to the centroids of the clusters detected by the modified TWINSPAN classification. 1=Cynodonto-Sorghetum halepensis; $2=$ Potentillo reptantis-Sorghetum halepensis var. with Elymus repens; $3=$ Potentillo reptantis-Sorghetum halepensis var. with Urtica dioica; $4=$ Potentillo reptantis-Sorghetum halepensis

and geophytes and by a low number of therophytes. As regards to chorotypes, both groups are featured by the dominance of widely distributed species. The Italian communities show a higher presence of Mediterranean, palaeotemperate, and archaeophyte taxa (Fig. 4).

\subsection{Description, syntaxonomy, and synecology of the detected communities}

The floristic, chorological, and ecological distinctiveness of the surveyed communities from those classified in the Cynodonto-Sorghetum halepensis allows us to describe a new association that we name Potentillo reptantis-Sorghetum halepensis. It includes an agricultural variant with Elymus repens and a meso-igrophilous variant with Urtica dioica.

Due to the frequency of species like Cichorium intybus, Daucus carota, and Picris hieracioides, we classified the Potentillo reptantis-Sorghetum halepensis in the class Artemisietea vulgaris, which includes the perennial ruderal vegetation of temperate and sub-Mediterranean Europe (Mucina et al. 2016). The presence of diagnostic elements like Elymus repens, Dittrichia viscosa, Jacobaea erucifolia, Pulicaria dysenterica, Reichardia picroides, Rumex crispus, Sixalix atropurpurea, and Verbena officinalis allows us classifying the new association in the alliance Inulo viscosae-Agropyrion repentis, which is a sub-Mediterranean vicariant of the 

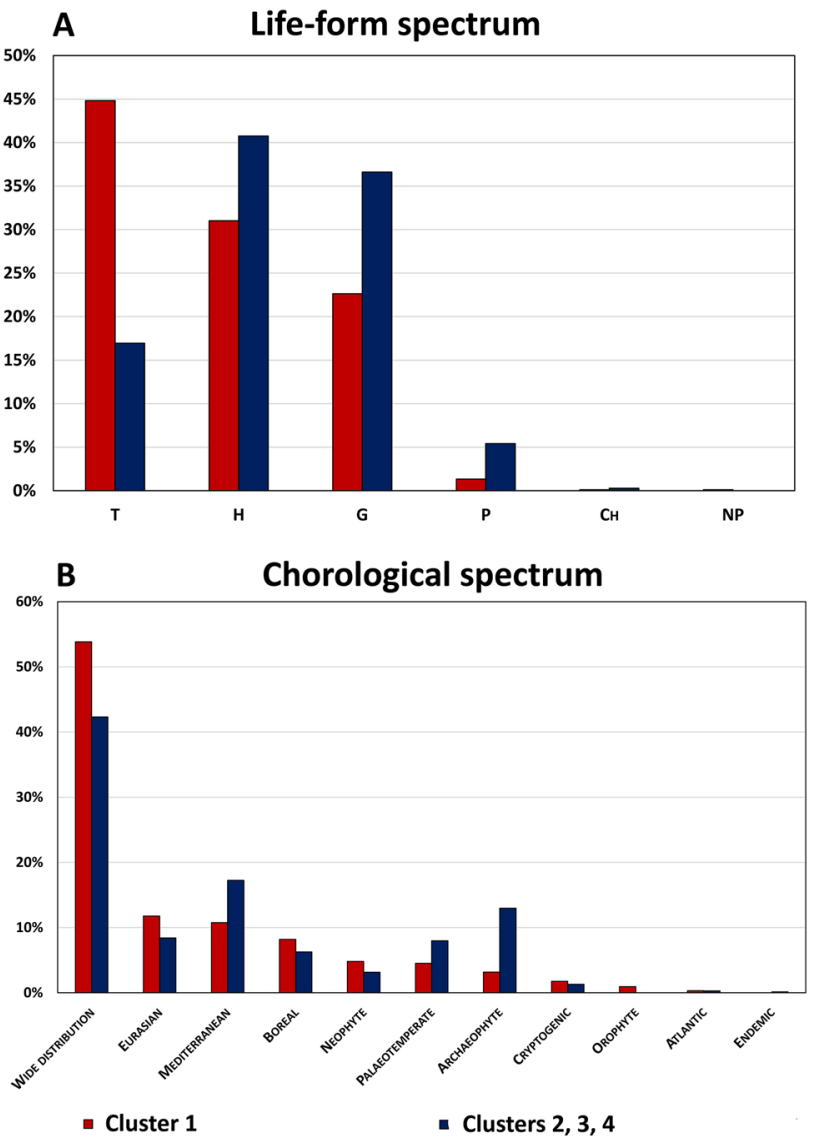

Fig. 4 Frequency-weighted life form (A) and chorological (B) spectra of the Balkan (cluster 1) and Italian (clusters 2, 3, and 4) communities

temperate Convolvulo arvensis-Agropyrion repentis, in the order Elytrigio repentis-Dittrichietalia viscosae. These syntaxa describe the anthropogenic (sub-)ruderal grasslands and herblands of sub-Mediterranean and Mediterranean Italian and Balkan peninsulas (alliance) and of Southern Europe (order) (Biondi et al. 2014; Mucina et al. 2016).

Potentillo reptantis-Sorghetum halepensis ass. nova Fanfarillo et Angiolini.

Type relevé: rel. 7 in Table 2 (Online Resource 1). Siena, Tuscany (WGS84: $43.314990^{\circ} \mathrm{N}, 11.316769^{\circ} \mathrm{E}$ ), 2020 July $18^{\text {th }}$, roadside flowerbed, $254 \mathrm{~m}$ a.s.l., aspect $=135^{\circ}$, slope $=10^{\circ}$, relevé area $=3 \mathrm{~m}^{2}$, vegetation height $=150 \mathrm{~cm}$, total cover $=100 \%$. Species (cover): Sorghum halepense (5), Cynodon dactylon (4), Potentilla reptans (2), Equisetum ramosissimum (+), Polygonum aviculare $(+)$, Convolvulus arvensis (+), Cichorium intybus (+), Avena barbata (r), Verbena officinalis (r).

Diagnostic species (characteristic and differential): Avena barbata, Cynodon dactylon, Convolvulus arvensis, Equisetum ramosissimum, Potentilla reptans, Sorghum halepense.

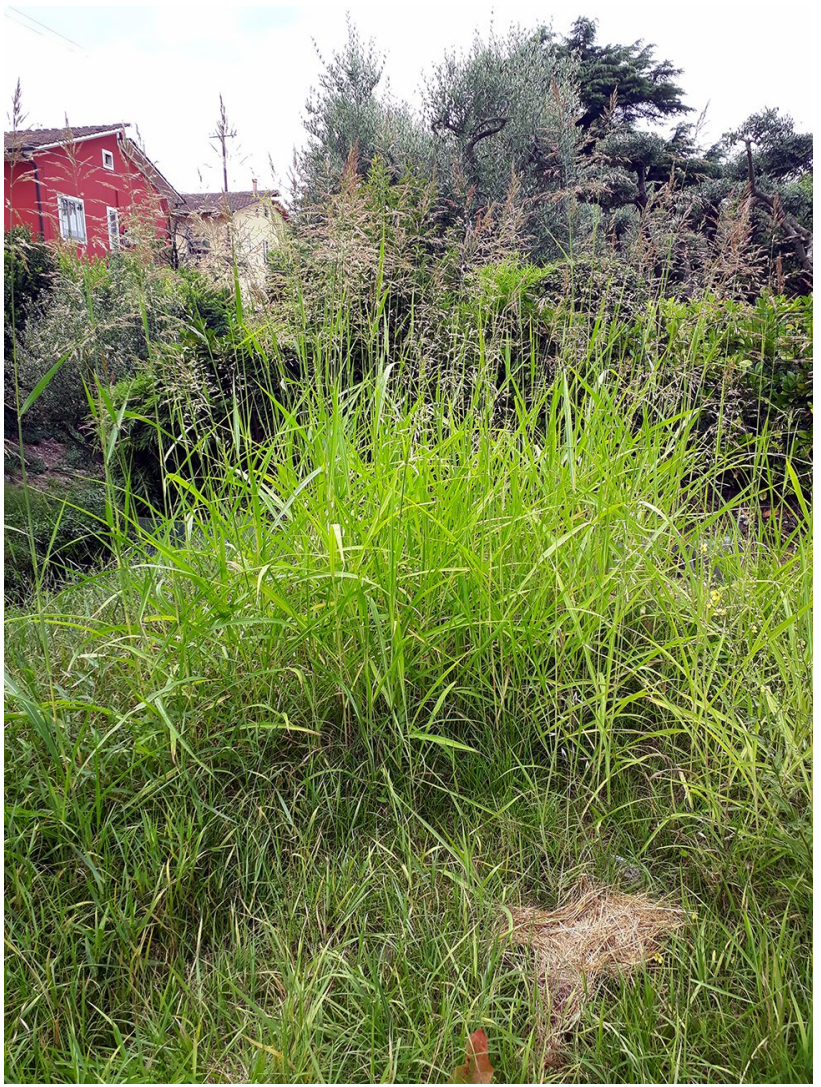

Fig. 5 Vegetation classified as the association Potentillo reptantisSorghetum halepensis. Altopascio (Tuscany, Italy), 2020 July 24th

Constant species: Cynodon dactylon, Convolvulus arvensis, Sorghum halepense.

Dominant species: Cynodon dactylon, Convolvulus arvensis, Sorghum halepense.

This vegetation type is represented by tall, speciespoor tufts of Sorghum halepense. The mean number of species is $7.5(\mathrm{SD}=2.7)$. A middle layer characterized by Equisetum ramosissimum is sometimes present. The lower layer is characterized by a high frequency of the rhizomatous grass Cynodon dactylon, usually with very high cover values. The rhizomatous climbing herb Convolvulus arvensis is constant and often abundantly present in the lower layer, accompanied by the creeping herb Potentilla reptans. There is also an occurrence of the winter annual Avena barbata, which is usually present with low covers and in its late phenological states (Fig. 5).

The community develops especially along roadsides, but it can be found in any ruderal and sub-ruderal open habitat with an average water availability and quickly desiccating soils. It has its phenological optimum between mid-summer and early autumn.

Agricultural variant with Elymus repens. 
This variant develops in vineyards managed with low intensities of agricultural practices, or occasionally in abandoned fields, field margins, and highly disturbed ruderal sites (e.g., frequently mown sites). In general, it results from conditions of higher disturbance caused by agricultural management, though disturbance levels are not comparable to those endured by arable vegetation due to reduced tillage intensities and frequencies. Sometimes, Elymus repens and Cynodon dactylon become dominant at the expense of Sorghum halepense. The constant presence of Convolvulus sepium suggests good levels of soil moisture availability. The presence of annual plants increases the mean species richness, which is $13.4(\mathrm{SD}=3.2)$.

Meso-hygrophilous variant with Urtica dioica (Fig. 6).

This community develops in sites with higher water availability at least during rainy periods, especially near and along roadside ditches, or where intermittent waterflows occur, e.g., in unpaved street gutters. It is enriched in mesohygrophilous elements like Galium album, Mentha spicata, M. suaveolens, Rubus ulmifolius, and Urtica dioica, whose presence increases the mean number of species per relevé to $10.5(\mathrm{SD}=2.9)$.

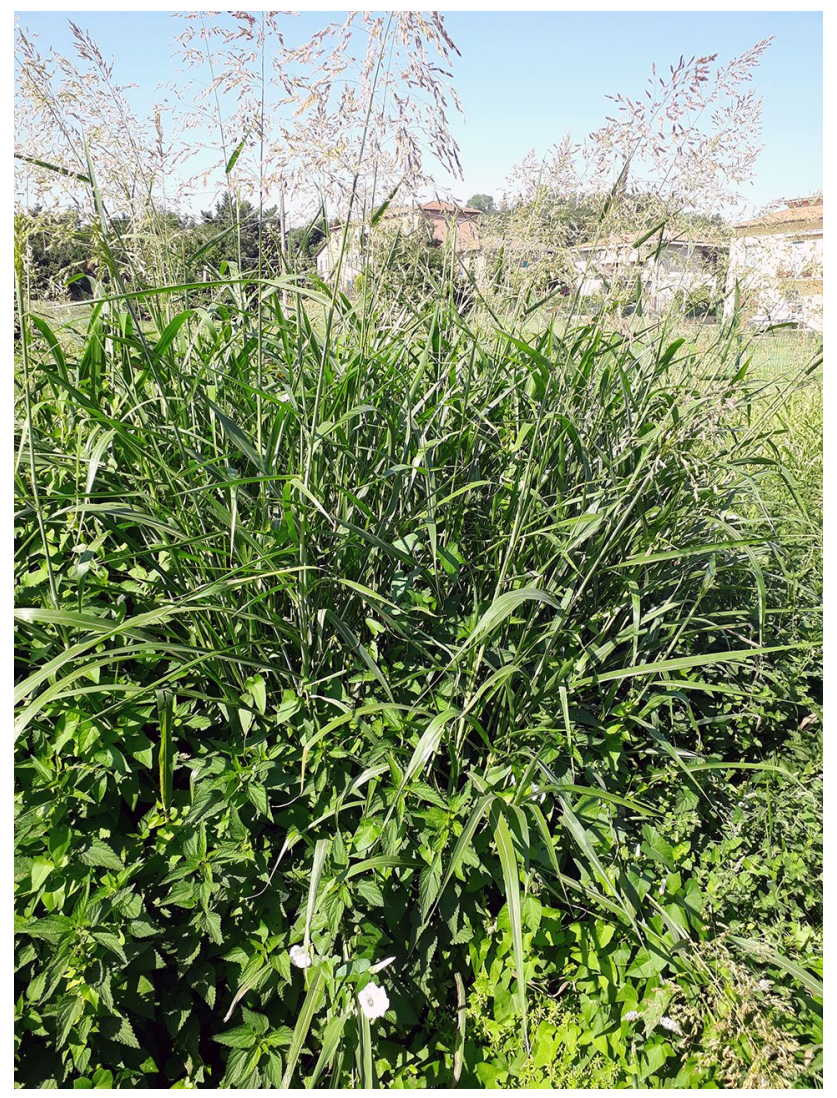

Fig. 6 Vegetation classified as the association Potentillo reptantisSorghetum halepensis var. with Urtica dioica. Sinalunga (Tuscany, Italy), 2020 July 31 st

\subsection{Distribution of the association Potentillo reptantis-Sorghetum halepensis}

According to our results, the communities classified in the association Potentillo reptantis-Sorghetum halepensis occur in peninsular Italy, Slovenia, and Kosovo (Fig. 7). Literature suggests its possible presence also in the Po Plain (De Marchi et al. 1979). We detected the association in its typical form all over the Italian Peninsula and, with only one relevé, in Kosovo. Conversely, the occurrence of the variant with Urtica dioica is currently known only from central Italy. We highlighted the presence of the variant with Elymus repens only for Slovenia and Tuscany, in Italy.

\subsection{Syntaxonomic scheme}

Artemisietea vulgaris Lohmeyer et al. in Tx. ex von Rochow1951.

Elytrigio repentis-Dittrichietalia viscosae Mucina 2016.

Inulo viscosae-Agropyrion repentis Biondi et Allegrezza 1996.

Potentillo reptantis-Sorghetum halepensis Fanfarillo et Angiolini ass. nov.

var. with Urtica dioica.

var. with Elymus repens.

\section{Discussion}

The analysis of our dataset revealed the existence of a new perennial vegetation type dominated by Sorghum halepense being widespread in peninsular Italy. The distinctiveness of the Potentillo reptantis-Sorghetum halepensis communities from those previously described for the Balkans was highlighted in terms of floristic, ecological, and chorological features.

In Italy, the order Elytrigio repentis-Dittrichietalia viscosae includes other (sub-)ruderal communities dominated by rhizomatous plants. Despite the structural affinities, such vegetation types are floristically different from the Potentillo reptantis-Sorghetum halepensis, at least with respect to the dominant and characteristic species. The alliance Inulo viscosae-Agropyrion repentis includes some associations rich in or dominated by rhizomatous species, e.g., the Agrostio stoloniferae-Agropyretum repentis or the Dauco carotae-Tussilaginetum farfarae from the badlands of central Italy (Biondi and Pesaresi 2004). Such plant communities are characterized by a higher floristic richness than Potentillo reptantis-Sorghetum halepensis, since the dominant species are less competitive than S. halepense. Conversely, the association Arundinetum plinianae (classified in the Inulo-Agropyrion as well) represents species-poor stands dominated by the rhizomatous grass Arundo plinii and it is very common 
Fig. 7 Currently known distribution of the association Potentillo reptantis-Sorghetum halepensis

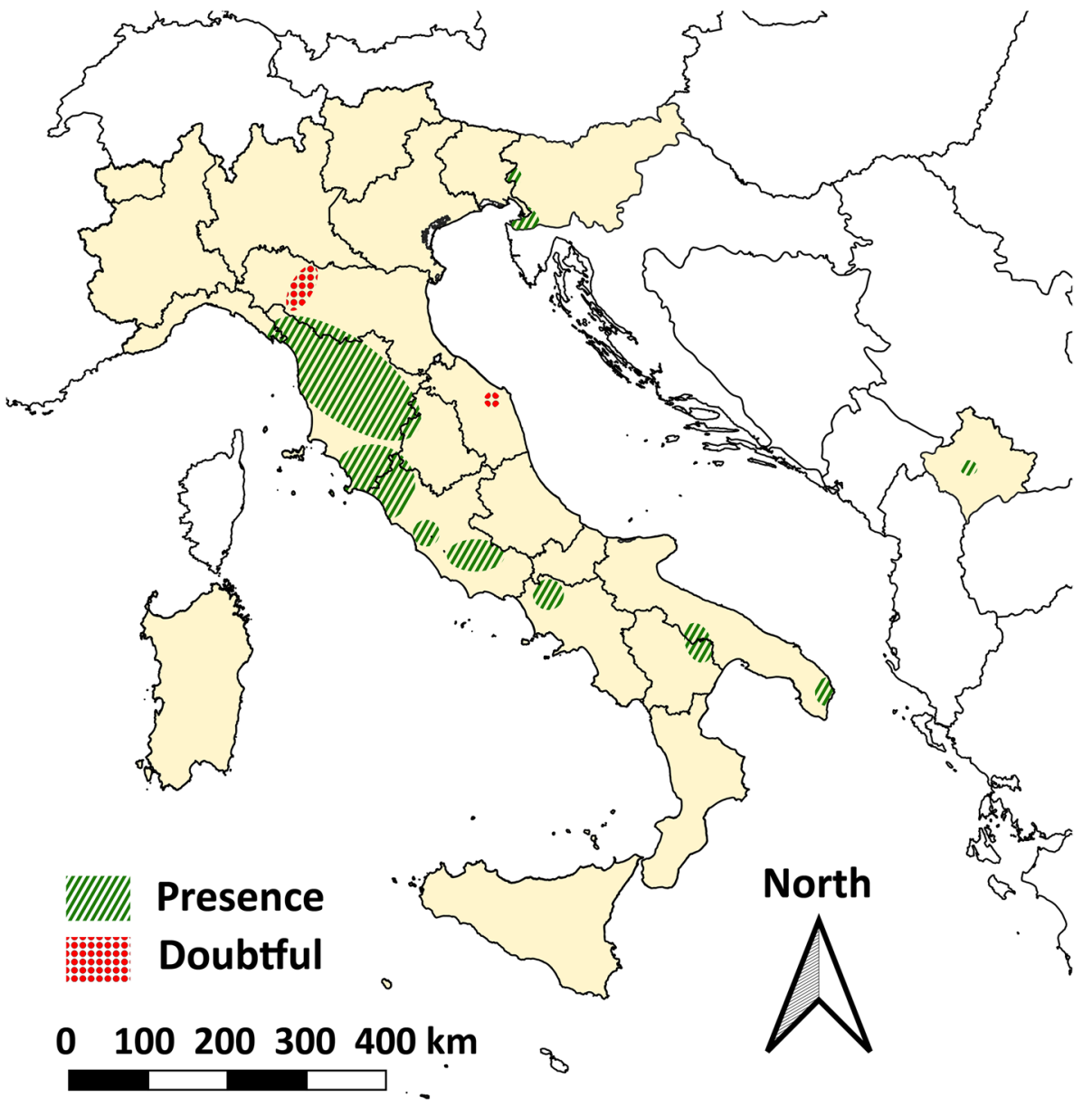

on the clayey slopes of peninsular Italy. In this community, like in Sorghum halepense-dominated stands, few species accompany the dominant one, with the presence of some shrubs in the most evolved aspects (Biondi et al. 1992). An alien-dominated, geophytic plant community showing phenological and ecological affinities with the Potentillo reptantis-Sorghetum halepensis is the Saponario-Artemisietum verlotiorum (Arction, Artemisietea vulgaris), which has its maximum development in summer-autumn and occurs on gravel bars, on quickly drying substrates (Baldoni and Biondi 1993). Another perennial ruderal community from the Inulo-Agropyrion, with a sporadic presence of Sorghum halepense, was detected on gravel bars of Tuscany. Such vegetation type is species-rich and dominated by hemicryptophytes like Dittrichia viscosa, thus being very different from the Potentillo-Sorghetum (Landi et al. 2002).

The main differences between the Potentillo reptantis-Sorghetum halepensis and the Cynodonto-Sorghetum halepensis are given by the degree of disturbance regime. Roadside Sorghum halepense-dominated vegetation is subject only to mowing and cutting, whereas communities of the Cynodonto-Sorghetum halepensis are under agricultural disturbance regimes, including tillage (Laban 1975). This explains the high occurrence of annual species of the class Stellarietea mediae s.l. (currently split into Chenopodietea, Digitario sanguinalis-Eragrostietea minoris, Papaveretea rhoeadis, and Sisymbrietea according to Mucina et al. 2016) like Amaranthus retroflexus, Chenopodium album, and Senecio vulgaris in the association Cynodonto-Sorghetum halepensis. Such species are almost absent in the association Potentillo reptantis-Sorghetum halepensis, which is characterized by a remarkable presence of hemicryptophytes of the class Artemisietea vulgaris (Medicago sativa, Picris hieracioides, Silene latifolia). The abundance of geophytes is also relevant (Cynodon dactylon, Equisetum ramosissimum).

In general, the high representation of widely distributed elements suggests that both associations Potentillo reptantis-Sorghetum halepensis and Cynodonto-Sorghetum halepensis are azonal, potentially cosmopolitan and cooccurring in the same areas. They could also be ecological vicariants in contexts of different types of anthropogenic disturbance. The association Potentillo reptantis-Sorghetum halepensis shows a higher occurrence of Mediterranean taxa and a lower occurrence of cosmopolitan species. The different presence of Mediterranean taxa derives from the different climatic and biogeographic conditions between the 
Italian Peninsula and the Balkans, while the higher occurrence of wide distribution species in Balkan communities might be linked to tillage (Laban 1975).

The dominant species Sorghum halepense reaches much higher cover values in the association Potentillo reptantis-Sorghetum halepensis, with a consequent lower species richness compared to the association Cynodonto-Sorghetum halepensis. Except for Cynodon dactylon and Convolvulus arvensis, no other species are usually able to reach high cover values in the association Potentillo reptantis-Sorghetum halepensis, due to the competition exerted by the dominant species. On the contrary, many other species may be dominant or co-dominant with Sorghum halepense in the association Cynodonto-Sorghetum halepensis, like Calepina irregularis, Elymus repens, and Salvia verticillata, some of which are diagnostic of the several sub-associations described by Laban (1975).

The inner variability detected in the association Potentillo reptantis-Sorghetum halepensis led us to highlight the existence of two different variants, linked to different conditions of moisture availability and disturbance. Given the potential wide distribution of the described communities, other variants or even sub-associations could be identified in future. The detection of the variant with Elymus repens suggests a possible dynamic linkage between the associations Potentillo reptantis-Sorghetum halepensis and Cynodonto-Sorghetum halepensis, since this variant can be interpreted as a dynamic stage linked to intermediate disturbance levels.

In the past, syntaxa identifying communities featured by Sorghum halepense were mainly described for arable vegetation (Baldoni 1995; Ştefan and Oprea 1997; Mitić et al. 2009; Nowak and Nowak 2013). Such vegetation types include plant communities that are dominated by annual species, classified in the class Stellarietea mediae s.l. Like the Cynodonto-Sorghetum halepensis, they are very different in floristic composition and ecology from the roadside vegetation here classified in the association Potentillo reptantis-Sorghetum halepensis. Consistently with our results, also other authors classified perennial vegetation dominated or characterized by Sorghum halepense in the class Artemisietea vulgaris (Fanelli 2002; Biondi et al. 2009; Denk and Berg 2014). The Italian communities from Marche previously classified as Cynodonto-Sorghetum halepensis could be possibly classified in the Potentillo reptantis-Sorghetum halepensis. Recognizing the perennial character of the detected communities, Biondi et al. (2009) classified them in the alliance Convolvulo arvensis-Agropyrion repentis and in the class Artemisietea vulgaris, though the Cynodonto-Sorghetum halepensis describes annual communities belonging to the class Stellarietea mediae s.l. Additionally, the gravel bank vegetation types detected by De Marchi et al. (1979) could be classified in the Potentillo reptantis-Sorghetum halepensis. However, we were not able to retrieve the relevés from these studies to include them in our analyses. On the contrary, the relevés from Fanelli (2002) were included in our analyses and classified in the Potentillo reptantis-Sorghetum halepensis.

The low species richness observed in the surveyed communities highlights the relevant competitive ability of the dominant species, with a consequent decrease of the levels of native plant diversity once it is established. Therefore, besides expert-based assessments, field data will be necessary in future to quantify the impact of Sorghum halepensedominated vegetation on native plant communities (Lazzaro et al. 2020).

\section{Conclusion}

In this work, we provided the first contribution to the phytosociological knowledge of roadside Sorghum halepensedominated vegetation in areas of southern Europe where this vegetation type is very common. Our analyses highlighted the distinctiveness of such communities from those of the Cynodonto-Sorghetum halepensis, an association of annual vegetation erroneously used as a reference for perennial Sorghum halepense-dominated communities of peninsular Italy. This allowed the description of the new association Potentillo reptantis-Sorghetum halepensis in the alliance Inulo viscosae-Agropyrion repentis and in the class Artemisietea vulgaris. Moreover, the detection of an agricultural variant featured by Convolvulus sepium and Elymus repens suggested a dynamical linkage between the Cynodonto-Sorghetum halepensis and the Potentillo reptantis-Sorghetum halepensis communities. Given the high representation of widely distributed species in the surveyed vegetation type, it is likely that the actual distribution of the association Potentillo reptantis-Sorghetum halepensis is much wider than that highlighted by our results, which supported its presence in Italy, Kosovo, and Slovenia.

Our work provides a first baseline for the knowledge of alien-dominated plant communities that are known to be negatively affecting some Natura 2000 habitats. Such vegetation is also a source of many noxious weeds for agriculture. Further research will allow a better understanding of roadside Sorghum halepense-dominated vegetation in terms of distribution, spread mechanisms, and its impacts on EU habitats and native plant communities.

\section{Other syntaxa mentioned in the text (in alphabetic order)}

Agrostio stoloniferae-Agropyretum repentis Biondi et Allegrezza 1996; Arundinetum plinianae Biondi, Brugiapaglia, Allegrezza et Ballelli 1992; Bidention tripartitae 
Nordhagen ex Klika et Hadač 1944; Chenopodietea Br.Bl. in Br.-Bl. et al. 1952; Chenopodion rubri (Tx. in Poli et J. Tx. 1960) Hilbig et Jage 1972; Convolvulo arvensisAgropyretum repentis Felfoldy 1943; Convolvulo arvensisAgropyrion repentis Görs 1967; Cynancho acuti-Sorghetum halepensis Ştefan et Oprea 1997; Cynodonto-Sorghetum halepensis (Laban 1974) Kojic 1979; Dauco carotae-Tussilaginetum farfarae Biondi, Brugiapaglia, Allegrezza et Ballelli 1989; Digitario sanguinalis-Eragrostietea minoris Mucina, Lososová et Šilc 2016; Hibisco trioni-Sorghetum halepensis Mitić et al. 2009; Isoëto-Nanojuncetea Br.-Bl. et Tx. in Br.-B1. et al. 1952; Littorelletea uniflorae Br.-Bl. et Tx. ex Westhoff et al. 1946; Panico sanguinalis-Polygonetum persicariae Pignatti 1953 sorghetosum halepensis Baldoni 1995; Papaveretea rhoeadis Brullo et al. 2001; Saponario-Artemisietum verlotiorum Baldoni et Biondi 1993; Setario ambiguae-Sorghetum halepensis Ştefan et Oprea 1997; Setario lutescentis-Sorghetum halepensis Ştefan et Oprea 1997; Sisymbrietea Gutte et Hilbig 1975; Sorghetum halepensis Ricardo et Vilamajó 2005; Stellarietea mediae Tx. et al. in Tx. ex von Rochow 1951.

Supplementary Information The online version contains supplementary material available at https://doi.org/10.1007/s12210-022-01050-3.

Funding F.K. was financed by the Slovenian Research Agency (research core funding No. P1-0236).

\section{Declarations}

Conflict of interest The authors declare no conflicts of interest/competing interests.

Ethics approval and consent to participate This article does not contain any studies with human participants or animals performed by any of the authors.

Open Access This article is licensed under a Creative Commons Attribution 4.0 International License, which permits use, sharing, adaptation, distribution and reproduction in any medium or format, as long as you give appropriate credit to the original author(s) and the source, provide a link to the Creative Commons licence, and indicate if changes were made. The images or other third party material in this article are included in the article's Creative Commons licence, unless indicated otherwise in a credit line to the material. If material is not included in the article's Creative Commons licence and your intended use is not permitted by statutory regulation or exceeds the permitted use, you will need to obtain permission directly from the copyright holder. To view a copy of this licence, visit http://creativecommons.org/licenses/by/4.0/.

\section{References}

Arthan W, McKain MR, Traiperm P, Welker CAD, Teisher JK, Kellogg EA (2017) Phylogenomics of Andropogoneae (Panicoideae: Poaceae) of Mainland Southeast Asia. Syst Bot 42(3):418-431. https://doi.org/10.1600/036364417X696023
Baldoni M (1995) Vegetazione infestante le colture erbacee delle Marche e dei piani carsici dell'Appennino umbro-marchigiano (Italia centrale) e serie di vegetazione [Weed vegetation of herbaceous crops in Marche and in the karst plateaus of the UmbriaMarche Apennine (central Italy) and vegetation series]. Colloques Phytosociologiques 24:787-812

Baldoni M, Biondi E (1993) La vegetazione del medio e basso corso del Fiume Esino (Marche - Italia centrale) [The vegetation of the middle and lower stretch of the Esino River (Marche - central Italy)]. Studia Botanica 11:209-257

Bartolucci F, Peruzzi L, Galasso G, Albano A, Alessandrini A, Ardenghi NMG, Astuti G, Bacchetta G, Ballelli S, Banfi E, Barberis G, Bernardo L, Bouvet D, Bovio M, Cecchi L, Di Pietro R, Domina G, Fascetti S, Fenu G, Festi F, Foggi B, Gallo L, Gottschlich G, Gubellini L, Iamonico D, Iberite M, JiménezMejías P, Lattanzi E, Marchetti D, Martinetto E, Masin R, Medagli P, Passalacqua NG, Peccenini S, Pennesi R, Pierini B, Poldini L, Prosser F, Raimondo FM, Roma-Marzio F, Rosati L, Santangelo A, Scoppola A, Scortegagna S, Selvaggi A, Selvi F, Soldano A, Stinca A, Wagensommer RP, Wilhalm T, Conti F (2018) An updated checklist of the vascular flora native to Italy. Plant Biosyst 152(2):179-303. https://doi.org/10.1080/11263504.2017.1419996

Biondi E, Pesaresi S (2004) The badland vegetation of the northerncentral Apennines (Italy). Fitosociologia 41(1):155-170

Biondi E, Brugiapaglia E, Allegrezza M, Ballelli S (1992) La vegetazione del litorale marchigiano (Adriatico centro-settentrionale) [The vegetation of coastal Marche (central-northern Adriatic)]. Coll Phytosoc N.s. 19:429-460

Biondi E, Zivkovic L, Esposito L, Pesaresi S (2009) Vegetation, plant landscape and habitat analyses of a fluvial ecosystem in central Italy. Acta Bot Gall 156(4):571-587. https://doi.org/10.1080/ 12538078.2009.10516178

Biondi E, Blasi C, Allegrezza M, Anzellotti I, Azzella MM, Carli E, Casavecchia S, Copiz R, Del Vico E, Facioni L, Galdenzi D, Gasparri R, Lasen C, Pesaresi S, Poldini L, Sburlino G, Taffetani F, Vagge I, Zitti S, Zivkovic L (2014) Plant communities of Italy: the vegetation Prodrome. Plant Biosyst 148(4):728-814. https:// doi.org/10.1080/11263504.2014.948527

Braun-Blanquet J (1964) Plant Sociology: the study of plant communities. Hafner Publishing Company, New York

Brullo S, Scelsi F, Spampinato G (2001) La vegetazione dell'Aspromonte. Studio Fitosociologico [The vegetation of Aspromonte. Phytosociological study]. Laruffa, Reggio Calabria.

Celesti-Grapow L, Alessandrini A, Arrigoni PV, Assini S, Banfi E, Barni E, Bovio M, Brundu G, Cagiotti MR, Camarda I, Carli E, Conti F, Del Guacchio E, Domina G, Fascetti S, Galasso G, Gubellini L, Lucchese F, Medagli P, Passalacqua NG, Peccenini S, Poldini L, Pretto F, Prosser F, Vidali M, Viegi L, Villani MC, Wilhalm T, Blasi C (2009) Inventory of the non-native flora of Italy. Plant Biosyst 143(2):386-430. https://doi.org/10.1080/ 11263500903431870

Chytrý M, Tichý L, Holt J, Botta-Dukát Z (2002) Determination of diagnostic species with statistical fidelity measures. J Veg Sci 13(1):79-90. https://doi.org/10.1111/j.1654-1103.2002.tb02025.x

De Marchi A, Zanotti Censoni AL, Corbetta E, Ghetti PE (1979) Cenosi macrofitiche alveali del torrente Parma in rapporto a morfologia e tipologia dei sedimenti [Macrophytic riverbed coenoses of the Parma river in relationship to morphology and sediment types]. Ateneo Parmense Acta Naturalia 15:221-240

Denk V, Berg C (2014) Do short-lived ruderal and arable weed communities reflect regional climate differences? A case study from SE Styria. Tuexenia 34:305-328. https://doi.org/10.14471/2014. 34.014

Fanelli G (2002) Analisi fitosociologica dell'area metropolitana di Roma [Phytosociological analysis of Rome metropolitan area]. Braun-Blanquetia 27:1-269 
Fanfarillo E, Kasperski A, Giuliani A, Abbate G (2019) Shifts of arable plant communities after agricultural intensification: a floristic and ecological diachronic analysis in maize fields of Latium (central Italy). Bot Lett 166(3):356-365. https://doi.org/10.1080/23818 107.2019.1638829

Fanfarillo E, Latini M, Iberite M, Bonari G, Nicolella G, Rosati L, Salerno G, Abbate G (2020) The segetal flora of winter cereals and allied crops in Italy: species inventory with chorological, structural and ecological features. Plant Biosyst 154(6):935-946. https://doi.org/10.1080/11263504.2020.1739164

Follak S, Essl F (2013) Spread dynamics and agricultural impact of Sorghum halepense, an emerging invasive species in Central Europe. Weed Res 53:53-60. https://doi.org/10.1111/j.1365-3180. 2012.00952.x

Follak S, Schleicher C, Schwarz M, Essl F (2017) Major emerging alien plants in Austrian crop fields. Weed Res 57:406-416. https://doi. org/10.1111/wre. 12272

Galasso G, Conti F, Peruzzi L, Ardenghi NMG, Banfi E, CelestiGrapow L, Albano A, Alessandrini A, Bacchetta G, Ballelli S, Bandini Mazzanti M, Barberis G, Bernardo L, Blasi C, Bouvet D, Bovio M, Cecchi L, Del Guacchio E, Domina G, Fascetti S, Gallo L, Gubellini L, Guiggi A, Iamonico D, Iberite M, Jiménez-Mejías P, Lattanzi E, Marchetti D, Martinetto E, Masin RR, Medagli P, Passalacqua NG, Peccenini S, Pennesi R, Pierini B, Podda L, Poldini L, Prosser F, Raimondo FM, Roma-Marzio F, Rosati L, Santangelo A, Scoppola A, Scortegagna S, Selvaggi A, Selvi F, Soldano A, Stinca A, Wagensommer RP, Wilhalm T, Bartolucci F (2018) An updated checklist of the vascular flora alien to Italy. Plant Biosyst 152(3):556-592. https://doi.org/10.1080/11263504. 2018.1441197

Giussani LM, Cota-Sánchez JH, Zuloaga FO, Kellogg EA (2001) A molecular phylogeny of the grass subfamily Panicoideae (Poaceae) shows multiple origins of $\mathrm{C} 4$ photosynthesis. Am J Bot 88:1993-2012. https://doi.org/10.2307/3558427

Heap I (2014) Herbicide resistant weeds. In: Pimentel D, Peshin R (eds) Integrated pest management. Springer, Dordrecht, pp 281-301

Holm LG, Plucknett DL, Pancho JV, Herberger JP (1977) The World's worst weeds: distribution and biology. University Press of Hawaii, Honolulu

ISPRA (2021) Carta geologica d'Italia alla scala 1:50000 [Geological map of Italy at the scale 1:50000]. https://www.isprambiente.gov. it/Media/carg/. Accessed 3 Feb 2021

Kaligarič M (1992) Vegetacija žitnih in vinogradnih plevelov v Koprskem Primorju [Vegetation of corn and vineyard weeds in the Koprsko Primorje region]. Dissertation, University of Ljubljana

Kashif M, Gul B, Khan H, Hidayat S, Amin M, Shakeel A, Ahmed I, Ahmad M (2015) Impact of Soil Moisture and Soil Depths on Resprouting Ability of Johnson Grass (Sorghum halepense L.) Rhizomes. Pak J Weed Sci Res 21:327-334

Laban A (1975) Ekološko-fitocenološka proučavanja korova u plantažnim voćnjacima SAP Kosovo kao osnove za iznalaženje najracionalnijih mera suzbijanja [Ecological-phytocoenological studies on weeds of fruit orchards in the Socialist Autonomous Province of Kosovo as a basis for finding the most rational control measures]. PhD Dissertation, University of Belgrade

Landi M, Angiolini C, De Dominicis V (2002) Analisi fitosociologica dei fiumi della Toscana meridionale: il tratto medio-basso del Merse (Italia centrale) [Phytosociological analysis of southern Tuscany rivers: the lower-middle stretch of the Merse (central Italy)]. Stud Bot 21:37-88

Latini M, Fanfarillo E, De Luca E, Iberite M, Abbate G (2020) The weed vegetation of the bean "Fagiolo Cannellino di Atina" and the red pepper "Peperone di Pontecorvo" PDO crops (Latium, central Italy). Plant Sociol 57(1):1-10. https://doi.org/10.3897/ pls2020571/01
Lazzaro L, Bolpagni R, Buffa G, Gentili R, Lonati M, Stinca A, Acosta ATR, Adorni M, Aleffi M, Allegrezza M, Angiolini C, Assini S, Bagella S, Bonari G, Bovio M, Bracco F, Brundu G, Caccianiga M, Carnevali L, Di Cecco V, Ceschin S, Ciaschetti G, Cogoni A, Foggi B, Frattaroli AR, Genovesi P, Gigante D, Lucchese F, Mainetti A, Mariotti M, Minissale P, Paura B, Pellizzari M, Perrino EV, Pirone G, Poggio L, Poldini L, Poponessi S, Prisco I, Prosser F, Puglisi M, Rosati L, Selvaggi A, Sottovia L, Spampinato G, Stanisci A, Venanzoni R, Viciani D, Vidali M, Villani M, Lastrucci L (2020) Impact of invasive alien plants on native plant communities and Natura 2000 habitats: state of the art, gap analysis and perspectives in Italy. J Environ Manage 274:111140. https://doi.org/10.1016/j.jenvman.2020.111140

Lucarini D, Gigante D, Landucci F, Panfili E, Venanzoni R (2015) The anArchive taxonomic Checklist for Italian botanical data banking and vegetation analysis: theoretical basis and advantages. Plant Biosyst 149(6):958-965. https://doi.org/10.1080/ 11263504.2014 .984010

Mitić B, Topić J, Ilijanić L, Jasprica N, Milović M, Ruščić M, Pandža M, Bogdanović S, Dolina K (2009) Kartiranje flore Dalmacije. Prioritetna područja: otok Pag, estuarij Krke, otok Vis i pučinski otoci, Pelješac i Mljet, tok Cetine [Mapping the flora of Dalmatia. Priority areas: the island of Pag, the Krka estuary, the island of Vis and the offshore islands, Pelješac and Mljet, the course of the Cetina]. University of Zagreb, Zagreb

Mucina L, Bültmann H, Dierßen K, Theurillat JP, Raus T, Čarni A, Sumberová K, Willner W, Dengler J, Gavilán García R, Chytrý M, Hájek M, Di Pietro R, Iakushenko D, Pallas J, Daniëls FJA, Bergmeier E, Santos Guerra A, Ermakov N, Valachovič M, Schaminée JHJ, Lysenko T, Didukh YP, Pignatti S, Rodwell JS, Capelo J, Weber HE, Solomeshch A, Dimopoulos P, Aguiar C, Hennekens SM, Tichý L (2016) Vegetation of Europe: hierarchical floristic classification system of vascular plant, bryophyte, lichen, and algal communities. Appl Veg Sci 19:3-264. https://doi.org/10.1111/avsc. 12257

Nowak S, Nowak A (2013) Weed communities of root crops in the Pamir Alai Mts, Tajikistan (Middle Asia). Acta Soc Bot Pol 82(2):135-146. https://doi.org/10.5586/asbp.2013.011

Oksanen J, Blanchet FG, Friendly M, Kindt R, Legendre P, McGlinn D, Minchin PR, O'Hara RB, Simpson GL, Solymos P, Henry M, Stevens H, Szoecs E, Wagner H (2020) vegan: Community Ecology Package. R package version 2.5-7. https://cran.r-proje ct.org/web/packages/vegan/index.html. Accessed 3 Feb 2021

Orsenigo S, Fenu G, Gargano D, Montagnani C, Abeli T, Alessandrini A, Bacchetta G, Bartolucci F, Carta A, Castello M, Cogoni D, Conti F, Domina G, Foggi B, Gennai M, Gigante D, Iberite M, Peruzzi L, Pinna MS, Prosser F, Santangelo A, Selvaggi A, Stinca A, Villani MC, Wagensommer RP, Tartaglini N, Duprè E, Blasi C, Rossi G (2021) Red list of threatened vascular plants in Italy. Plant Biosyst 155(2):310-335. https://doi.org/10.1080/ 11263504.2020.1739165

Peerzada AM, Ali HH, Hanif Z, Bajwa AA, Kebaso L, Frimpong D, Iqbal N, Namubiru H, Hashim S, Rasool G, Manalil S, van der Meulen A, Chauhan BS (2017) Eco-biology, impact, and management of Sorghum halepense (L.) Pers. Biol Invasions. https://doi.org/10.1007/s10530-017-1410-8

Pesaresi S, Biondi E, Casavecchia S (2017) Bioclimates of Italy. J Maps 13(2):955-960. https://doi.org/10.1080/17445647.2017. 1413017

Pignatti S, Menegoni P, Pietrosanti S (2005) Bioindicazione attraverso le piante vascolari. Valori di indicazione secondo Ellenberg (Zeigerwerte) per le specie della Flora d'Italia [Bioindication through vascular plants. Ellenberg indicator values (Zeigerwerte) for the species of the Flora of Italy]. Braun-Blanquetia 39:3-97 
Pignatti S, Guarino R, La Rosa M (2017-2019) Flora d'Italia [Flora of Italy]. Second Edition. Edagricole - Edizioni Agricole di New Business Media, Bologna.

Poldini L, Oriolo G, Mazzolini G (1998) The segetal vegetation of vineyards and crop fields in Friuli-Venezia Giulia (NE Italy). Stud Geobot 16:5-32. https://www.openstarts.units.it/handle/10077/ 15277

Portal to the Flora of Italy (2021 onwards) Portale della Flora d'Italia/ Portal to the Flora of Italy, version 2021.1. http://dryades.units. it/floritaly/. Accessed 23 Dec 2021

Ricardo Nápoles NE, Vilamajó Alberdi D, Bastart Ortiz JA (2005) Merremio umbellatae-Lippion strigulosae Ricardo All. Nova. Acta Bot Cuba 191:31-35. http://repositorio.geotech.cu/jspui/bitst ream/1234/3406/1/Merremio\%20umbellatae-Lippion\%20strigulo sae\%20Ricardo\%20All.\%20Nova.pdf

Roleček J, Tichý L, Zelený D, Chytrý M (2009) Modified TWINSPAN classification in which the hierarchy respects cluster heterogeneity. J Veg Sci 20:596-602. https://doi.org/10.1111/j.1654-1103. 2009.01062.x

Seebens H, Blackburn TM, Dyer EE, Genovesi P, Hulme PE, Jeschke JM, Pagad S, Pyšek P, Winter M, Arianoutsou M, Bacher S, Blasius B, Brundu G, Capinha C, Celesti-Grapow L, Dawson W, Dullinger S, Fuentes N, Jäger H, Kartesz J, Kenis M, Kreft H, Kühn I, Lenzner B, Liebhold A, Mosena A, Moser D, Nishino M, Pearman D, Pergl J, Rabitsch W, Rojas-Sandoval J, Roques A, Rorke S, Rossinelli S, Roy HE, Scalera R, Schindler S, Štajerová K, Tokarska-Guzik B, van Kleunen M, Walker K, Weigelt P, Yamanaka T, Essl F (2017) No saturation in the accumulation of alien species worldwide. Nat Commun 8:14435. https://doi.org/ 10.1038/ncomms 14435

Seljak G (1989) Plevelna vegetacija vinogradov in sadovnjakov na Goriškem in vpliv večletne rabe nekaterih herbicidov na spremembo dominantnosti plevelnih vrst [Weed vegetation of vineyards and orchards in the Goriška region and the influence of long-term use of certain herbicides on the change in the dominance of weed species]. Dissertation, University of Ljubljana.

Ștefan N, Oprea A (1997) A contribution to the weed phytocoenology with Sorghum halepense (L.) Pers. Studii şi cercetări de biologie - seria biologie vegetală 49(1-2):37-42

Stinca A, Musarella CM, Rosati L, Laface VLA, Licht W, Fanfarillo E, Wagensommer RP, Galasso G, Fascetti S, Esposito A, Fiaschi T, Nicolella G, Chianese G, Ciaschetti G, Salerno G, Fortini P, Di
Pietro R, Perrino EV, Angiolini C, De Simone L, Mei G (2021) Italian vascular flora: new findings, updates and exploration of floristic similarities between regions. Diversity 13(11):600. https:// doi.org/10.3390/d13110600

Theurillat JP, Willner W, Fernández-González F, Bültmann H, Čarni A, Gigante D, Mucina L, Weber H (2021) International Code of Phytosociological Nomenclature. 4th edition. Appl Veg Sci 24:e12491. https://doi.org/10.1111/avsc.12491

Tichý L, Chytrý M (2006) Statistical determination of diagnostic species for site groups of unequal size. J Veg Sci 17:809-818. https:// doi.org/10.1111/j.1654-1103.2006.tb02504.x

Tichý L (2002) JUICE, software for vegetation classification. J Veg Sci 13:451-453. https://www.jstor.org/stable/3236542

Vazquez-Garcia JG, Palma-Bautista C, Rojano-Delgado AM, De Prado R, Menendez J (2020) The first case of glyphosate resistance in Johnson grass (Sorghum halepense (L.) Pers.) in Europe. Plants 9:313. https://doi.org/10.3390/plants9030313

Venables WN, Ripley BD (2002) Modern applied statistics with S, 4th edn. Springer, New York

Viciani D, Vidali M, Gigante D, Bolpagni R, Villani M, Acosta ATR, Adorni M, Aleffi M, Allegrezza M, Angiolini C, Assini S, Bagella S, Bonari G, Bovio M, Bracco F, Brundu G, Buffa G, Caccianiga M, Carnevali L, Ceschin S, Ciaschetti G, Cogoni A, Di Cecco V, Foggi B, Frattaroli AR, Genovesi P, Gentili R, Lazzaro L, Lonati M, Lucchese F, Mainetti A, Mariotti M, Minissale P, Paura B, Pellizzari M, Perrino E, Pirone G, Poggio L, Poldini L, Poponessi S, Prisco I, Prosser F, Puglisi M, Rosati L, Selvaggi A, Sottovia L, Spampinato G, Stanisci A, Stinca A, Venanzoni R, Lastrucci L (2020) A preliminary checklist of the alien-dominated vegetation in Italy. Plant Sociol 57(1):29-54. https://doi.org/10.3897/ pls2020571/04

Vila-Aiub MM, Balbi MC, Gundel PE, Ghersa CM, Powles SB (2007) Evolution of glyphosate-resistant Johnson grass (Sorghum halepense) in glyphosate-resistant soybean. Weed Sci 55(6):566571. https://doi.org/10.1614/WS-07-053.1

Publisher's Note Springer Nature remains neutral with regard to jurisdictional claims in published maps and institutional affiliations. 